Plant Tissue Cult. \& Biotech. 22(2): 127-136, 2012 (December)

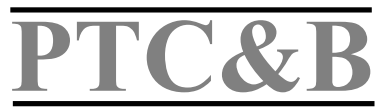

\title{
Assessment of Genetic Diversity of Chili Cultivars Using RAPD Markers
}

\author{
M.M. Uddin, M.I. Khalil*, M.S. Haque and M.B. Meah ${ }^{1}$ \\ Department of Biotechnology, Bangladesh Agricultural University, Mymensingh-2202, \\ Bangladesh
}

Key words: Genetic diversity, Chili cultivars, RAPD markers

\begin{abstract}
Random amplified polymorphic DNA (RAPD) assay was performed to estimate genetic polymorphisim in ten chili cultivars. Out of 12 primers four (OPA11, OPB03, OPB04 and OPB17) showed amplification of genomic DNA and generated 21 distinct score able bands of which 17 (80.95\%) were polymorphic. The highest percentage (85.71) polymorphic locus was found in OPB03 while the lowest (66.67) in OPA11. The highest genetic distance was computed between Jamalpur Balujuri and Matal marich with the lowest genetic identity as against the lowest genetic distance between Hajari marich and Balujuri marich. The UPGMA dendogram indicated segregation of ten chili varieties and genotypes into two main clusters. Variety Bogra marich and Matal marich formed cluster 1 and Balujuri marich, Deshi marich, Jamalpuri balujuri, Bindu marich, Syloti, Hajari, Biroli city, and the genotype Ausadhebrara grouped in cluster 2. The result indicates the genetic diversity among the chili cultivars and RAPD marker could be used for improvement of chili varieties.
\end{abstract}

\section{Introduction}

Chili (Capsicum spp.) is one of the most important spice crops in Bangladesh, and cultivated throughout the world including the tropics, subtropics and also temperate regions (Pickersgill 1997). Chili rich in vitamins A, C and E is being used as spice, condiment, vegetable, culinary supplement, medicine and as ornamental plant (Berke and Shieh 2001). Chili is widely grown in all parts of Bangladesh round the year. But the average yield of chili is very low compared to other countries of the world (FAO 2007). Due to the low yield its annual

*Author for correspondence: Plant Pathology Division, Bangladesh Institute of Nuclear Agriculture, Mymensingh-2202, Bangladesh. <ibrahim_bina@yahoo.com>. ${ }^{1}$ Department of Plant Pathology, Bangladesh Agricultural University, Mymensingh-2202, Bangladesh. 
production cannot meet the total requirement of the country. This could be due to many constraints such as unavailability of suitable cultivars, biotic and abiotic stresses.

The analysis of genetic diversity and relatedness between or within different species, populations and individuals is a prerequisite towards effective utilization and protection of plant genetic resources (Weising et al. 1995). There is a lot of variability among chili genotypes in Bangladesh. Some of these genotypes might have resistance to biotic and abiotic stresses that would be utilized in a breeding program by traditional as well as modern techniques like Agrobacterium-mediated gene transfer.

Molecular markers have many advantages such as abundance in polymorphism, no pleiotropic effect, less affected by environment and subjected to rapid detection (Sing et al. 2005). Among the molecular markers, RAPD has been widely used for the identification of genetic relationship between cultivars (Faruque et al. 2011, Makari et al. 2009, Biswas et al. 2009), for species identification (Welsh and McClelland 1990). The advantages of using RAPDs in gentic studies are, it requires small amount of DNA, short primers of arbitrary sequences, the rapidity to screen for polymorphism, easy, fast and also cost effective (Welsh and McClelland 1990). Livingstone et al. (1999) carried out research work to create a genetic map of Capsicum (pepper) from an interspecific $\mathrm{F}_{2}$ population consisting of 11 large and 2 small linkage groups. Makari et al. (2009) carried out RAPD analysis of chili germplasms. Therefore, the objective of the study was to assess genetic diversity between chili cultivars using RAPD marker that could facilitate the chili breeders to develop new varieties for higher yield and also for tolerant to stresses.

\section{Materials and Methods}

Ten chili cultivars were used for the molecular characterization through RAPD technique. The experiment was carried out in the Biotechnology Laboratory of the Bangladesh Institute of Nuclear Agriculture, Mymensingh, Bangladesh. Fresh leaf samples collected from 21-day-old seedlings were used for DNA extraction. The harvested leaf samples were kept in $-80^{\circ} \mathrm{C}$ freezer until extraction. Modified CTAB mini-prep method was followed to extract DNA from leaf samples (Kabir 2007). The quality of the DNA was verified by electrophoresis on a $0.8 \%$ agarose gel in TBE (Tris-boric acid-EDTA) buffer. The concentration of the DNA samples was determined using a UV spectrophotometer at $260 \mathrm{~nm}$.

RAPD reactions were maintained following the process of Williams et al. (1990) with some modifications. The screening of primer was done with 12 
arbitrary decamer primers (Bengalore Genei, India). Four primers producing a good score apple and reproducible bands were selected for subsequent RAPD analysis of chili cultivars (Table 1). PCRs were performed on each DNA sample in a $10.0 \mu \mathrm{l}$ reaction mixture containing $1 \times$ PCR buffer $(10 \mathrm{mM}$ Tris $\mathrm{HCl}, \mathrm{pH} 8.5$; $50 \mathrm{mM} \mathrm{KCl}$ and $15 \mathrm{mM} \mathrm{MgCl}_{2}$ ), $10 \mathrm{mM}$ each dNTPs (Bengalore Genei, India), 5 pmols primer, $2 \mathrm{U}$ of Taq DNA polymerase (Bengalore Genei), $100 \mathrm{ng}$ of genomic DNA. The reaction with each primer was replicated thrice to check the reproducibility of DNA. DNA amplification was carried out in a DNA thermocycler (Biometra, Germany) at the following thermal profile: initial denaturation for $3 \mathrm{~min}$ at $94^{\circ} \mathrm{C}$ followed by 41 cycles of 1 min denaturation at $94^{\circ} \mathrm{C}, 1 \mathrm{~min}$ annealing at $35^{\circ} \mathrm{C}$ and extension at $72^{\circ} \mathrm{C}$ for $2 \mathrm{~min}$. A final extension step at $72^{\circ} \mathrm{C}$ for $10 \mathrm{~min}$ was allowed for complete extension of all amplified fragments (Kabir 2007). Amplified fragments were separated on a 1.5\% agarose (Invitrogen, Canada) gel in 1X TBE buffer along with 20 bp DNA weight marker (Bengalore Genei, India) for 2 hours at 100V. Gel was stained with ethidium bromide solution $(0.1 \mu \mathrm{g} / \mathrm{ml})$ for $20 \mathrm{~min}$. Finally fragments were visualized under UV-transilluminator and photographed by Gel Documentation System (Biometra, Germany).

The amplified bands were visually scored as present (1) and absent (0) separately for each individual and each primer. The scores were pooled to create a single data matrix. This was used to estimate polymorphic loci, Nei (1972) genetic diversity, genetic distance and a UPGMA dendrogram using computer program, POPGENE (Version 1.31) (Yeh et al. 1999).

\section{Results and Discussion}

The RAPD technique provides sufficient polymorphisms for characterization of different varieties and genotypes of chili. The four primers generated 21 distinct bands of which 17 were considered as polymorphic. The percentage of polymorphic loci was $(80.95 \%)$ indicating a higher level of polymorphism (Table 1). The four primers generated (5.25) score able bands per primer and 4.25 polymorphic RAPD markers per primer. Biswas et al. (2009) selected four arbitrary primers after screening, those generated a total of 76 score able bands of which 44 were polymorphic, with an average of 19 amplicons per primer. Among the four primers, OPB03 produced maximum number of polymorphic bands that indicated a high level of polymorphism as against the primer OPA11 generated the least number of polymorphic bands (Table 1).

The banding patterns of different chili varieties and genotypes using 4 primers are shown in Figs 1 to 4 . Band size ranging from 110 to $400 \mathrm{bp}$ of PCR amplification products scored for primers. The reproducibility of the banding 
pattern often chili cultivars was confirmed by three replicated reactions with the same primer. Strong and weak bands were produced in the RAPD reactions. Weak bands produced from low homology between the primer and the pairing site on the DNA strand (Thormann et al. 1994). A diverse level of polymorphism in different crops has been reported in eggplant (57.89\%) by Biswas et al. (2009), in tomato (90.19\%) by Moonmoon (2006) and in chili (90\%) Paran et al. (1998).

Table 1. RAPD primers with corresponding bands score and their size range together with polymorphic bands observed in ten chili varieties.

\begin{tabular}{llcccc}
\hline $\begin{array}{l}\text { Primer } \\
\text { code }\end{array}$ & $\begin{array}{l}\text { Sequences } \\
\left(5^{\prime}-3^{\prime}\right)\end{array}$ & $\begin{array}{c}\text { Size } \\
\text { ranges } \\
(\mathrm{bp})\end{array}$ & $\begin{array}{c}\text { Total number } \\
\text { of bands } \\
\text { scored }\end{array}$ & $\begin{array}{c}\text { Number of } \\
\text { polymorphic } \\
\text { bands }\end{array}$ & $\begin{array}{c}\text { Proportion of } \\
\text { polymorphic } \\
\text { loci }(\%)\end{array}$ \\
\hline OPA11 & CAA TCG CCG T & $180-120$ & 3 & 2 & 66.67 \\
OPB03 & CAT CCC CCT G & $200-120$ & 7 & 6 & 85.71 \\
OPB04 & GGA CTG GAG T & $400-110$ & 5 & 4 & 80.00 \\
OPB17 & GAC CGC TTG T & $400-140$ & 6 & 5 & 83.33 \\
Total & - & - & 21 & 17 & 315.71 \\
Average & - & - & 5.25 & 4.25 & 80.95 \\
\hline
\end{tabular}

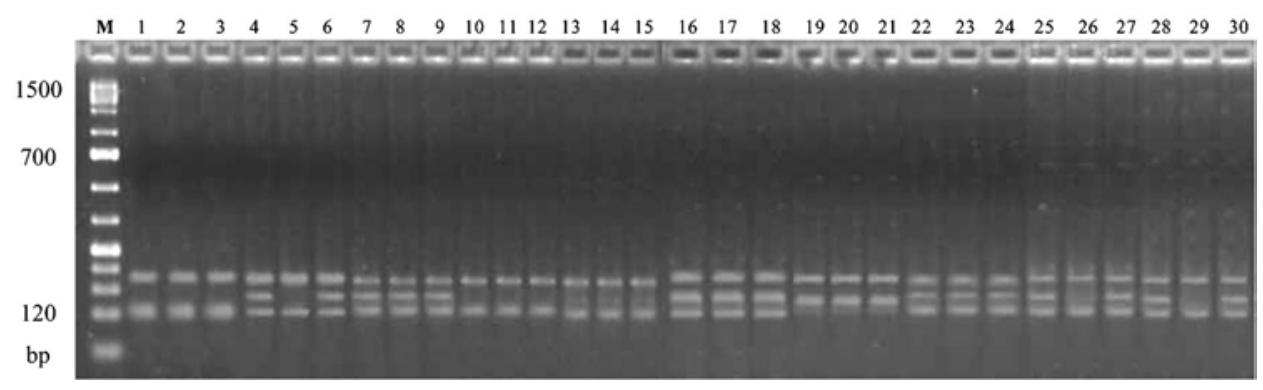

Fig. 1. RAPD profiles of ten chili varieties using primer OPA11. M: 20 bp DNA ladder. Lane 1 - 3: Bogra marich, 4 - 6: Matal marich, 7 - 9: Balujuri marich, 10 - 12: Deshi marich, 13 - 15: Jamalpuri balujuri, 16 - 18: Bindu marich, 19 - 21: Syloti, 22 - 24: Hajari, 25 - 27: Biroli city and 28 - 30 : Ausadhebrara.

Intra genotype similarity indices $\left(\mathrm{S}_{\mathrm{i}}\right)$ were higher, they ranged from 86.67 to $100.00 \%$ (Table 2). The highest intra genotype similarity indices $\left(\mathrm{S}_{\mathrm{i}}\right)$ were observed in Bogra marich, Balujuri marich, Deshi marich, Jamalpuri balujuri, Bindu marich, Syloti marich and Hajari marich (100.00\%), whereas the lowest intra genotype similarity indices were found in Biroli city marich (92.43\%) (Table 2 ). The highest $S_{i}$ value disclosed lower genetic variability within the individuals which was more homogenous than those of Biroli city in which $S_{i}$ value was found the lowest. 
Table 2. Summary of bands sharing based similarity indices within and between individuals of ten different chili varieties.

\begin{tabular}{llllll}
\hline Varieties & \multicolumn{5}{c}{ Band sharing values (\%) } \\
\cline { 2 - 6 } & OPA11 & OPB03 & OPB04 & OPB17 & Average \\
\hline Bogra marich & 100.00 & 100.00 & 100.00 & 100.00 & 100.00 \\
Matal marich & 86.67 & 93.94 & 100.00 & 92.59 & 93.30 \\
Balujuri marich & 100.00 & 100.00 & 100.00 & 100.00 & 100.00 \\
Deshi marich & 100.00 & 100.00 & 100.00 & 100.00 & 100.00 \\
Jamalpuri balujuri & 100.00 & 100.00 & 100.00 & 100.00 & 100.00 \\
Bindu marich & 100.00 & 100.00 & 100.00 & 100.00 & 100.00 \\
Syloti & 100.00 & 100.00 & 100.00 & 100.00 & 100.00 \\
Hajari & 100.00 & 100.00 & 100.00 & 100.00 & 100.00 \\
Biroli city & 86.67 & 90.47 & 92.59 & 100.00 & 92.43 \\
Ausadhebrara & 86.67 & 100.00 & 100.00 & 90.47 & 94.28 \\
Average & 96.00 & 98.44 & 99.26 & 98.30 & 98.00 \\
\hline
\end{tabular}

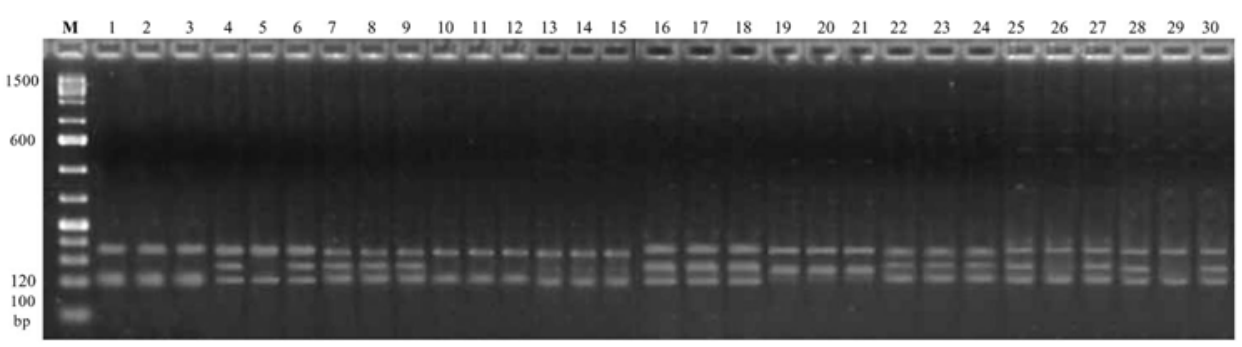

Fig. 2. RAPD profiles of ten chili varieties using primer OPB03. M: 20 bp DNA ladder. Lane 1 - 3: Bogra marich, 4 - 6: Matal marich, 7 - 9: Balujuri marich, 10 - 12: Deshi marich, 13 - 15: Jamalpuri balujuri, 16 - 18: Bindu marich, 19 - 21: Syloti, 22 - 24: Hajari, 25 - 27: Biroli city and 28 - 30: Ausadhebrara.

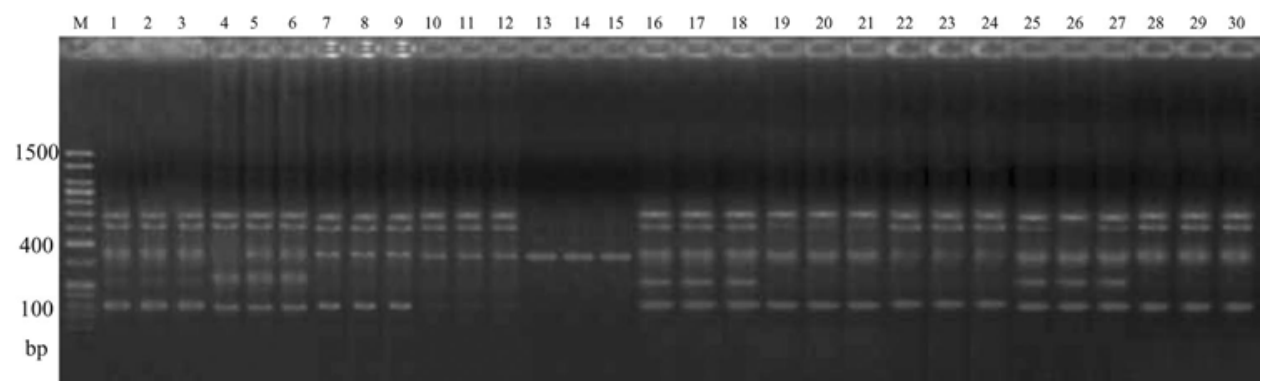

Fig. 3. RAPD profiles of ten chili varieties using primer OPB04. M: 20 bp DNA ladder. Lane 1 - 3: Bogra marich, 4 - 6: Matal marich, 7 - 9: Balujuri marich, 10 - 12: Deshi marich, 13 - 15: Jamalpuri balujuri, 16 - 18: Bindu marich, 19 - 21: Syloti, 22 - 24: Hajari, 25 - 27: Biroli city and 28 - 30: Ausadhebrara. 
The values of pairwise comparison of Nei's (1972) genetic distance among ten chili varieties and genotypes computed from combined data from the four primers ranged from $0.0488-0.7490$ (Table 3). The genetic distance value between variety Jamalpuri balujuri and Matal marich was highest $(0.7490)$ with the lowest genetic identity (0.4728) among the other pairwise variety and genotype. The genetic distance between variety Hajari and Balujuri marich was the lowest $(0.0488)$ with the highest genetic identity (0.9524). From the difference between the highest and the lowest genetic distance value there were wide variations among 10 chili varieties and genotypes. High genetic variability within varieties and significant difference between varieties indicate rich genetic material of a species. This study indicated that the variety Jamalpuri balujuri and Matal marich showed the highest genetic variation, while the lowest genetic variation was observed between variety Hajari and Balujuri marich, the two latter cultivars can be used as parental source for breeding line to improve chili varieties. Moonmoon (2006) reported that assessment of genetic diversity, molecular markers were superior to morphological, biochemical and other methods like pedigree and heterosis.

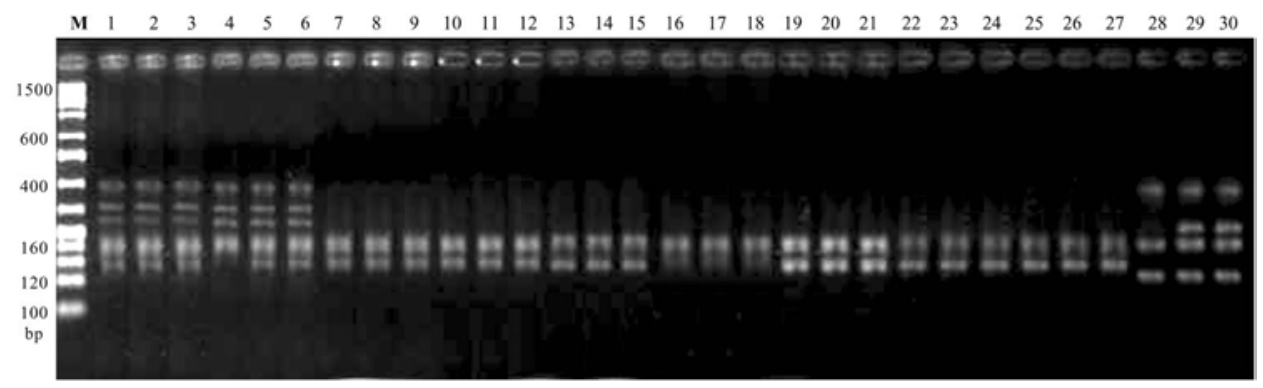

Fig. 4. RAPD profiles of ten chili varieties using primer OPB17. M: 20bp DNA ladder, Lane 1-3: Bogra marich, 4-6: Matal marich, 7-9: Balujuri marich, 10-12: Deshi marich, 13-15: Jamalpuri balujuri, 1618: Bindu marich, 19-21: Syloti, 22-24: Hajari, 25-27: Biroli city and 28-30: Ausadhebrara.

Dendrogram based on Nei's (1972) genetic distance using UPGMA indicated segregation of ten chili varieties and genotypes into two main clusters. Variety Bogra marich and Matal marich formed cluster-1 and the remaining eight varieties grouped in cluster-2 (Fig. 5). In cluster-1 Bogra marich, formed sub cluster-1 and Matal marich formed sub cluster-2. Again in cluster-2 Jamalpuri balujuri formed sub cluster-1, and seven entries formed sub cluster-2. Again in sub cluster-1, Bindu marich alone formed sub sub cluster-1 and remaining six entries formed sub sub cluster-2. 
Table 3. Summary of Nei's genetic identity (above diagonal) and genetic distance (below diagonal) values between ten chili varieties.

\begin{tabular}{lccccccccccc}
\hline Variety & $\begin{array}{c}\text { Bogra } \\
\text { marich }\end{array}$ & $\begin{array}{c}\text { Matal } \\
\text { marich }\end{array}$ & $\begin{array}{c}\text { Balujuri } \\
\text { marich }\end{array}$ & $\begin{array}{c}\text { Deshi } \\
\text { marich }\end{array}$ & $\begin{array}{c}\text { Jamalpuri } \\
\text { balujuri }\end{array}$ & $\begin{array}{c}\text { Bindu } \\
\text { marich }\end{array}$ & Syloti & $\begin{array}{c}\text { Hajari } \\
\text { Biroli city }\end{array}$ & $\begin{array}{c}\text { Ausadh- } \\
\text { ebrara }\end{array}$ \\
\hline Bogra marich & $* * * *$ & 0.8108 & 0.6190 & 0.7143 & 0.6190 & 0.5714 & 0.6190 & 0.6667 & 0.6627 & 0.7315 \\
Matal marich & 0.2097 & $* * * *$ & 0.6133 & 0.5146 & 0.4728 & 0.7197 & 0.5563 & 0.6057 & 0.5734 & 0.6034 \\
Balujuri marich & 0.4796 & 0.4889 & $* * * *$ & 0.8095 & 0.7143 & 0.7619 & 0.8095 & 0.9524 & 0.8032 & 0.7315 \\
Deshi marich & 0.3365 & 0.6644 & 0.2113 & $* * * *$ & 0.8095 & 0.6667 & 0.7143 & 0.8571 & 0.8602 & 0.7878 \\
Jamalpuri balujuri & 0.4796 & 0.7490 & 0.3365 & 0.2113 & $* * * *$ & 0.6667 & 0.6190 & 0.6667 & 0.7197 & 0.5927 \\
Bindu marich & 0.5596 & 0.3289 & 0.2719 & 0.4055 & 0.4055 & $* * * *$ & 0.5714 & 0.7143 & 0.7538 & 0.6827 \\
Syloti & 0.4796 & 0.5864 & 0.2113 & 0.3365 & 0.4796 & 0.5596 & $* * * *$ & 0.8571 & 0.7614 & 0.6340 \\
Hajari & 0.4055 & 0.5014 & 0.0488 & 0.1542 & 0.4055 & 0.3365 & 0.1542 & $* * * *$ & 0.8525 & 0.7803 \\
Biroli city & 0.4114 & 0.5561 & 0.2192 & 0.1506 & 0.3289 & 0.2826 & 0.2726 & 0.1595 & $* * * *$ & 0.7551 \\
Ausadhebrara & 0.3127 & 0.5051 & 0.3127 & 0.2385 & 0.5230 & 0.3817 & 0.4558 & 0.2481 & 0.2809 & $* * * *$ & \\
\hline
\end{tabular}

Assessment of Genetic Diversity of Chili Cultivars 
In sub sub cluster-2, Ausadhebra marich formed group 1 and Balujuri marich, Deshi marich, Syloti, Hajari, Biroli city formed group-2, respectively. In group-2, Deshi marich and Biroli city formed sub group-1 and Balujuri, Syloti, Hajari, formed sub group-2. In sub group-2, Syloti formed sub sub group-1 and Balujuri marich, Hajari, formed sub sub group-2. Variety Hajari was closer to the Balujuri marich with the least genetic distance (0.0488), so they fall under sub sub group-2 and the highest genetic distance (0.7490) was found among Jamalpuri balujuri and rest of the varieties and genotypes. That's why Jamalpuri balujuri alone formed one cluster and rest of varieties and genotypes formed another cluster. Except variety Jamalpuri balujuri other varieties and genotypes fall under cluster-2. These varieties and genotypes probably are identical based on some morphological characters.

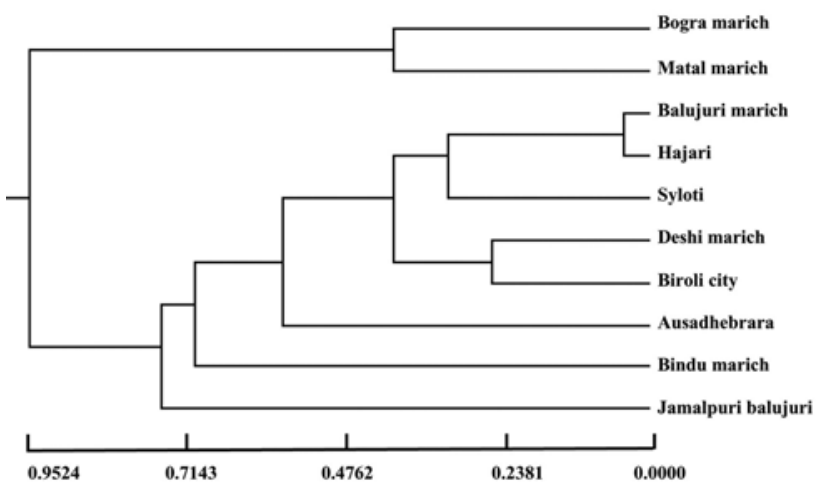

Fig. 5. UPGMA dendogram based on Nei's (1972) genetic distance, summarizing data on differentiation in ten chili cultivars according to RAPD analysis.

Akbar et al. (2010) reported that 25 Capsicum genotypes were grouped in four clusters. This grouping further strengthened previous other findings (Knapp et al. 2004) that DNA based data can reliably be used for studying the phylogenetic relationship among various accessions of a species based on geographic origin.

The polymorphism detected among the accessions can be used in breeding programme to maximize the use of genetic resources as well as improve chili varieties. From this investigation, it was revealed that the highest genetic identity (0.9524) remains between Balujuri marich and Hajari marich. On the other hand, the lowest (0.4728) genetic identity was observed between the Balujur marich and Matal marich. These findings indicated that Balujuri marich vs Hajari and Matal marich vs Balujuri marich could be used in plant breeding program for development of new chili varieties. RAPD markers provide a fast and efficient tool for genetic variability assessment and are currently used in plant genetic resources management. It is also evident from the dendrogram that the 
genotypes Jamalpuri balujuri and Matal marich were most distantly related to each other and hence it is recommended that these two genotypes should be used in a hybridization program to create maximum genetic diversity for the improvement of Capsicum crop in Bangladesh.

\section{Acknowledgements}

This investigation was supported by the USDA Grants (USDA-ARS-122). The authors are grateful to Biotechnology Division, Bangladesh Institute of Nuclear Agriculture for providing laboratory facilities.

\section{References}

Akbar N, Ahmad H, Ghafoor S, Begum K, Afridi SG, Muhammad I and Khan IA (2010) Estimation of genetic diversity in Capsicum germplasm using randomly amplified polymorphic DNA. Asian J. Agric. Sci. 2(2): 53-56.

Berke TG and Shieh SC (2001) Capsicum, chillies, paparika, bird's eye chilli. In Peter KV (Ed.) Handbook of Herbs and Spices. Wood head publishing Ltd., Cambridge, pp. 111-122.

Biswas MS, Akhond AAY, Alamin M, Khatun M and Kabir MR (2009) Genetic relationship among ten promising eggplant varieties using RAPD markers. Plant Tissue Cult. \& Biotech. 19(2): 119-126.

FAO (2007). FAO (Food and Agriculture Organization) Production Yearbook. Food and Agriculture Organization of the United Nations. Rome, Italy, 55: 333.

Faruque MO, Meah MB, Begum SN and Khalil MI (2011) Study of genetic variation in eggplant cultivars of Bangladesh through RAPD marker and its relatedness to red rot disease reaction. Bangladesh J. Agric. 36(1): 11-19.

Kabir MM (2007) Molecular characterization of $\mathrm{F}_{3}$ offspring of eggplant crosses for resistance to Phomosis blight and fruit rot. M.S. thesis. Dept. of Plant Pathology. Bangladesh Agricultural University, Mymensingh. p. 102.

Knapp S, Bohs L, Nee M and Spooner DM (2004) Solanaceae. A model for linking genomics with biodiversity. Comp. Funct. Genom. 5: 285-291.

Livingstone KD, Lackney VK, Blauth JR, Wijk RV and Jahn MK (1999) Genome mapping in Capsicum and the evolution of structure in the Solanaceae. Genetics 152: 1183-1202.

Makari HK, Patil HSR, Abhilash M and Kumar HDM (2009) Genetic diversity in commercial varieties of chilli as revealed by RAPD method. Indian J. Sci. Technol. 2(4): 91-94.

Moonmoon S (2006) Random amplified polymorphic DNA markers (RAPD) for genetic variation study among tomato varieties. M.S. Thesis. Dept. of Biotechnology. Bangladesh Agricultural University, Mymensingh. pp. 34-51.

Nei M (1972) Genetic distance between populations. American Nat. 106: 283-292.

Paran I, Aftergoot E and Shifriss C (1998) Variation in Capsicum annuum revealed by RAPD and AFLP markers. Euphytica 99(3): 167-173. 
Pickersgill B (1997) Genetic resources and breeding of Capsicum spp. Euphytica 96(1): 129133.

Sing AK, Singh M, Singh AK, Singh R, Kumar S and Kalloo G (2005) Genetic diversity within the genus Solanum (Solanaceae) as revealed by RAPD markers. Curr. Sci. 90: 711-714.

Thormann CE, Ferreira ME, Camargo LEA, Tivang JG and Osborn TC (1994) Comparison of RFLP and RAPD markers for estimating genetic relationships within and among Cruciferous species. Theor. Appl. Genet. 88: 973-980.

Weising K, Atkinson RG and Gardner RC (1995) Genomic fingerprinting by microsatellite-primed PCR: A critical evaluation. PCR Meth. Appl. 4: 249-255.

Welsh J and McClelland M (1990) Fingerprinting genomes using PCR with arbitrary primers. Nucleic Acids Res. 18: 7213-7218.

Williams JGK, Kubelik AR, Livak KJ, Rafalski JA and Tingey SV (1990) DNA polymorphism amplified by arbitrary primers are useful as genetic markers. Nucleic Acids Res. 18: 6531-6535.

Yeh FC, Yang RC, Boyle TBJ, Ye ZH and Mao JX (1999) POPGENE, the user-friendly software for population genetic analysis. Molicular Biology and Biotechnology Centre, University of Alberta, Canada. 